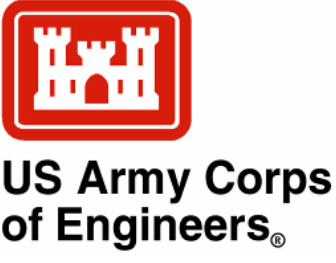

\title{
Regional Sediment Management (RSM) Principles in Flood Recovery: Incorporating RSM after the 2011 Missouri River Flood
}

by Paul M. Boyd

PURPOSE. This Coastal and Hydraulics Engineering Technical Note (CHETN) summarizes actions undertaken during 2011 and 2012 to incorporate US Army Corps of Engineers (USACE) Regional Sediment Management (RSM) principles into a wide variety of projects as part of flood recovery and reconstruction on the Missouri River. Significant damage was caused by the 2011 Missouri River flood, and mitigation of sediment impacts and repair of infrastructure were given a high priority in an effort to return the flood protection system to acceptable flood protection levels.

THE 2011 MISSOURI RIVER FLOOD. The Missouri River Mainstem System is made up of six large reservoirs with a total storage volume of nearly 75 million acre-feet (MAF). The dams were constructed between 1933 and 1965, and are operated as a system to meet eight congressionally authorized project purposes. Figure 1 shows the layout of the Missouri River Mainstem Reservoirs.

In May 2011, rainfall of historic proportions fell over a wide reach of the upper Missouri River basin. This rainfall, coupled with heavy snowpack, resulted in the need to discharge high flows through many of the mainstem reservoirs. These flows caused flooding and redistributed sediment, which resulted in damage to both private property and infrastructure along the river corridor.

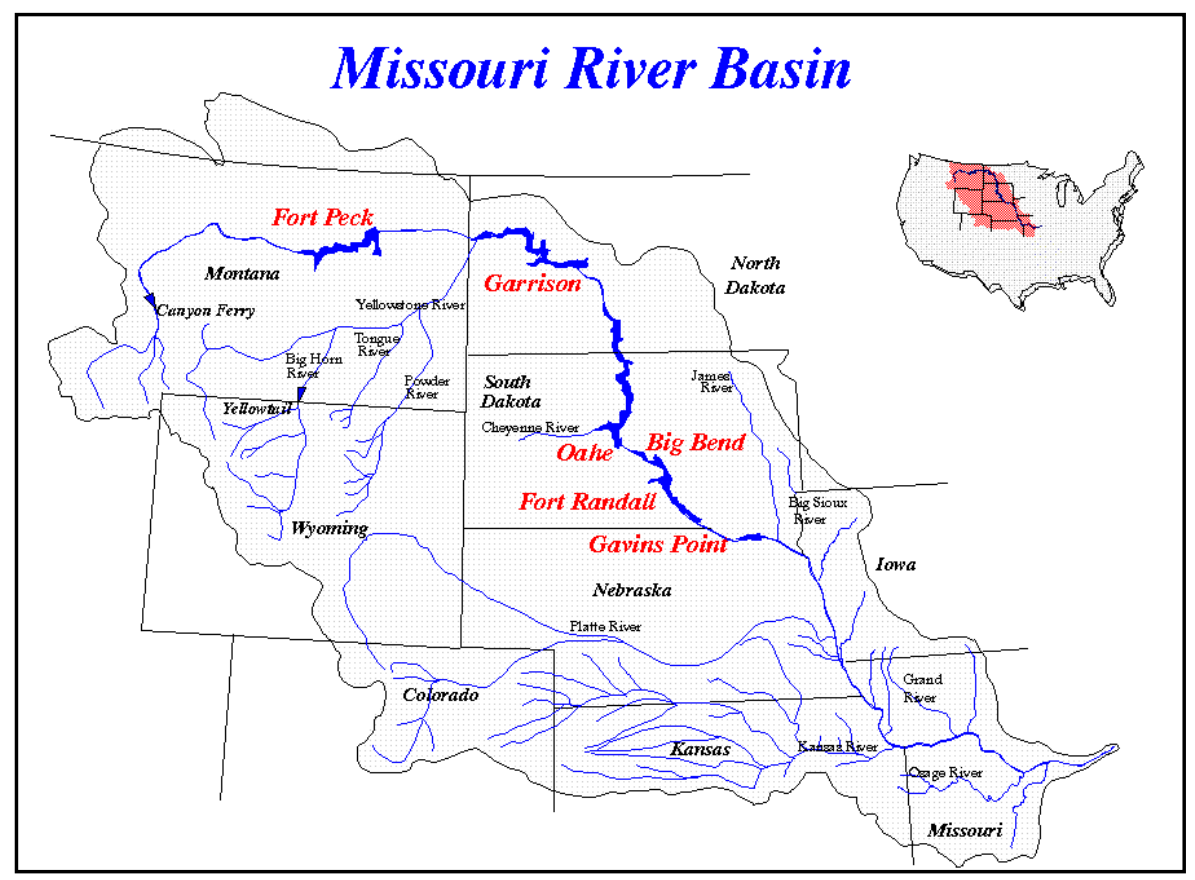

Figure 1. Missouri River mainstem reservoirs.
In an effort to quantify the effect of the reservoir system on the flood magnitude, the USACE Missouri River Basin Water Management Division projected the magnitude and duration of flows on the Missouri River during 2011 that would have resulted from an unregulated river (Figure 2). This figure shows the measured (actual regulated) and predicted (unregulated natural) hydrographs at Sioux City, IA (USACE 2012). 


\section{J une 2013}

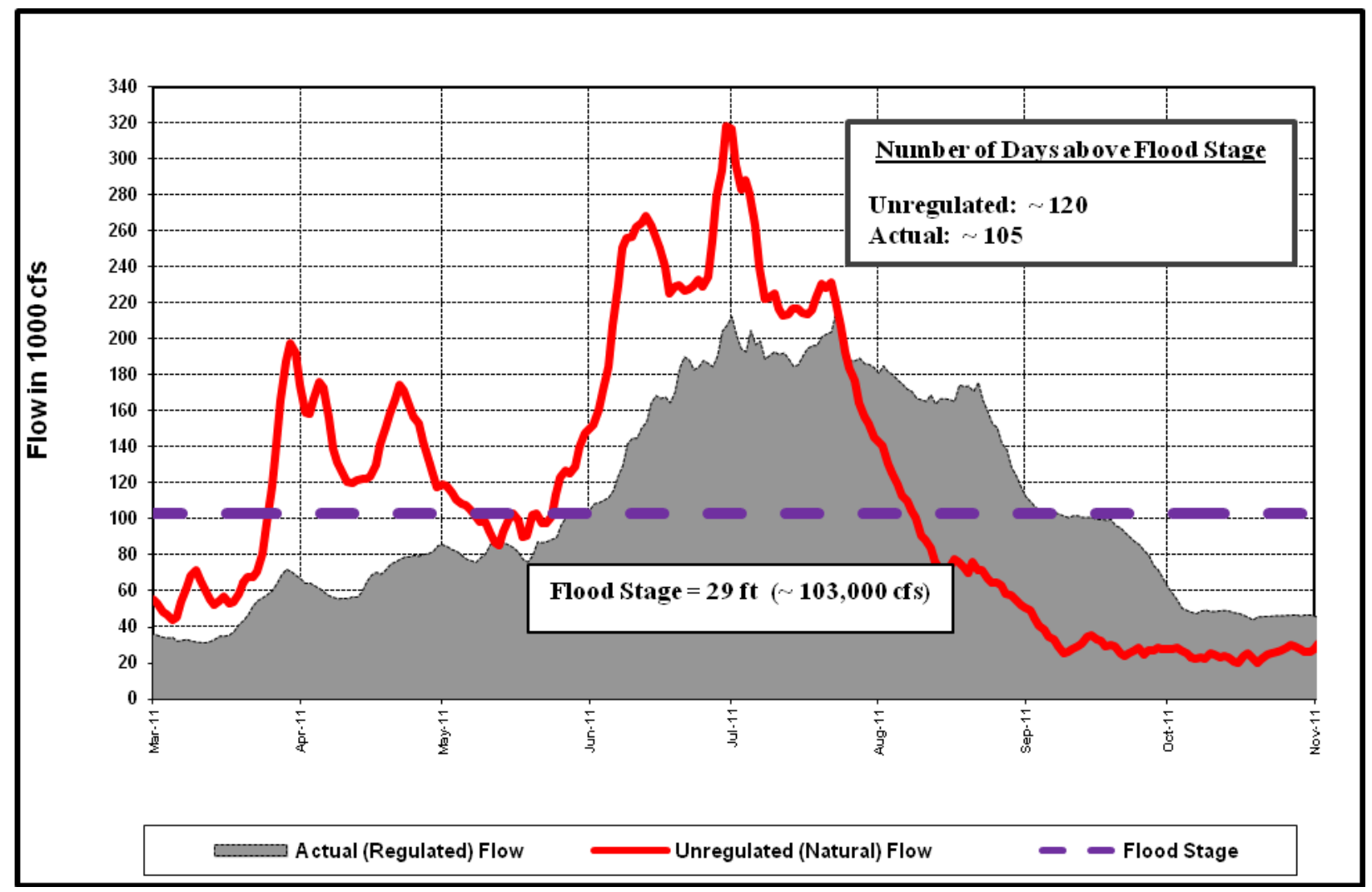

Figure 2. Measured (actual regulated flow) and predicted (unregulated natural flow) hydrographs of the Missouri River at Sioux City, IA.

After the flood waters receded, significant work was required to re-establish the full functionality of the Missouri River flood protection system. Damage included bank and channel erosion, levee failures, and deposition of vast amounts of sediment transported during the flood. When an aggressive schedule was set to complete repairs along the entire length of the river, the need to maximize speed, minimize cost, and reduce environmental impacts led to discussions about using the sediment that the flood deposited as a building block for recovery. Finding opportunities to use local sediment resources to deliver benefits to multiple programs aligns directly with the tenets of the USACE RSM program.

RSM OPPORTUNITIES IN MISSOURI RIVER FLOOD RECOVERY. As floodwaters receded in the fall of 2011, a large effort began to rehabilitate, reconstruct, and restore the Missouri River flood protection system to acceptable performance levels. These efforts were coordinated through an Omaha System Restoration Team (OSRT) of project managers who oversaw hundreds of projects from small to very large. Of these projects, a few select efforts showed potential to incorporate RSM principles into the recovery planning. Not every project could integrate the RSM principles, but a few that were moderately-to-fully successful are summarized here. 
Hamburg Bend Chute Shallow Water Habitat. The Hamburg Bend Chute complex is located on the Missouri River just below Nebraska City, NE, between river miles (RM) 552 and 556. The two chutes, the "Upper" on the Nebraska side and the "Lower" on the Missouri side, were constructed to create shallow water habitat for the endangered Pallid Sturgeon. The Upper Chute was constructed in 1994 and has been widening during the past 17 years. Control structures limit the chute flow and width, but not channel sinuosity. During moderate flows, the Upper Chute directs approximately 8 to 10\% of the river flow into the chute. During the sustained duration 2011 event high flood stages, the control structures were damaged and a considerably larger percentage of the river flow entered the chute.

At a large bend centered within the chute, significant erosion along the outer bank threatened a Federal levee that protects adjacent homes and farmland. The eroded chute bank approached the toe of the levee causing considerable concern regarding stability. In addition to the erosion on the outer bank, a point bar formed as the channel migrated. Figure 3 shows the design drawing for repairing the levee toe.

Approximately 30,000 tons of riprap were placed to re-establish the bank in front of the scour hole. Sediment was needed to fill and stabilize the scour hole between the riprap bank and the toe of the levee. The volume required to fill the scour hole exceeded the material available in the point bar that was to be dredged to provide fill and open up the chute channel. Therefore, an additional sediment source was required. Trucking and dredging were both considered; dredging was the more economical and timely option.

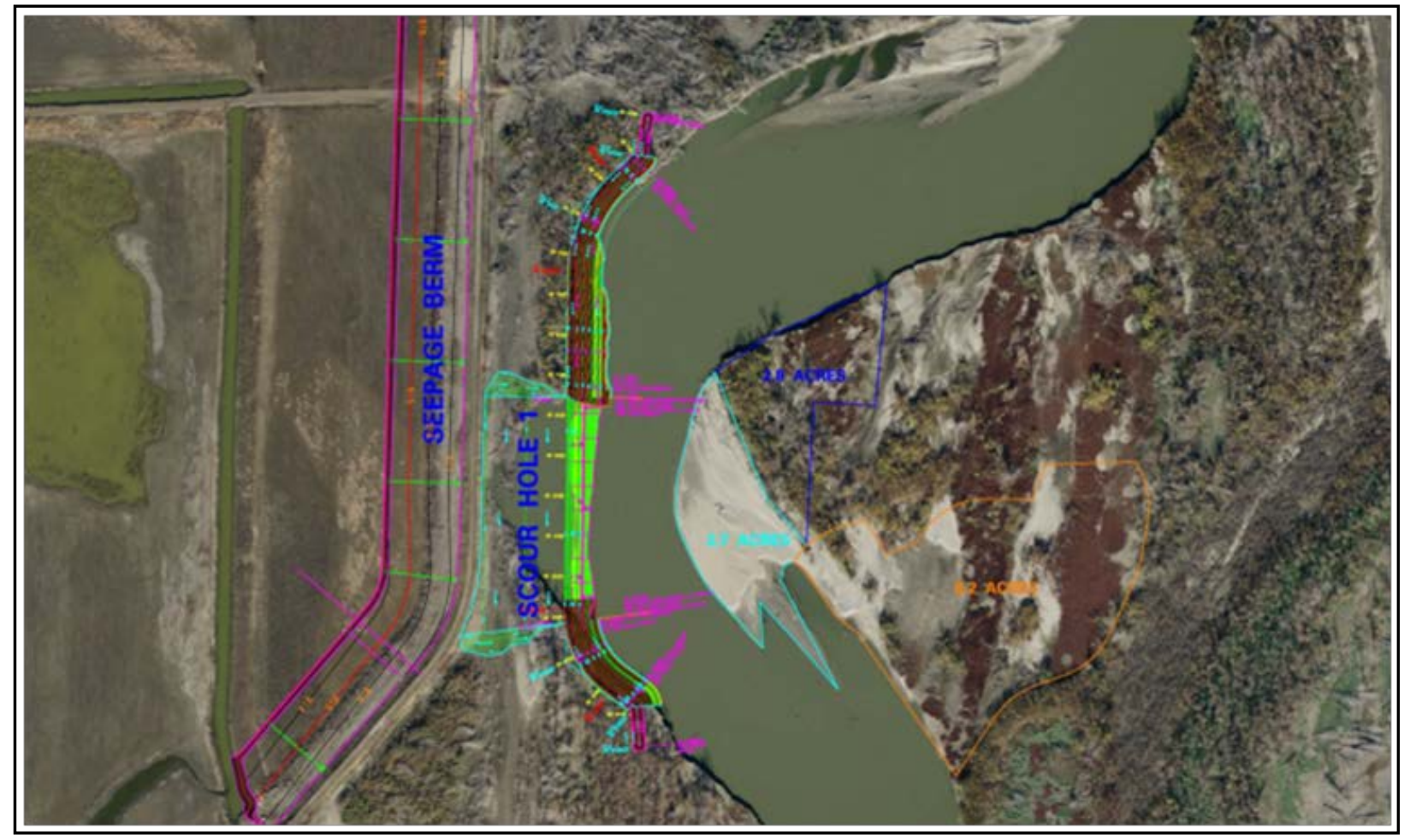

Figure 3. Upper Hamburg Bend Chute, Missouri River, repair plan. 


\section{J une 2013}

In the process of identifying a dredge material source, the design team consulted with engineers and biologists from the Missouri River Recovery Program (MRRP) tasked with designing and building appropriate habitat areas for the endangered Pallid Sturgeon. The MRRP worked with the design team to set the location, shape, and depth of an area that would meet the volume needs of the construction project, and that would create a backwater habitat area that qualifies as shallow water habitat. Completion of the project also included adding seepage blankets in multiple areas along the landward side of the levee. At the Upper Hamburg Chute site, less than $1 \%$ of the seepage blanket material was sourced from the dredging. However, at a second site just upstream, coarse sediments deposited in the river channel provided approximately $50 \%$ of the fill material needed. Figure 4 shows the final constructed repair, with the new levee toe on the left and the shallow water habitat backwater on the right.

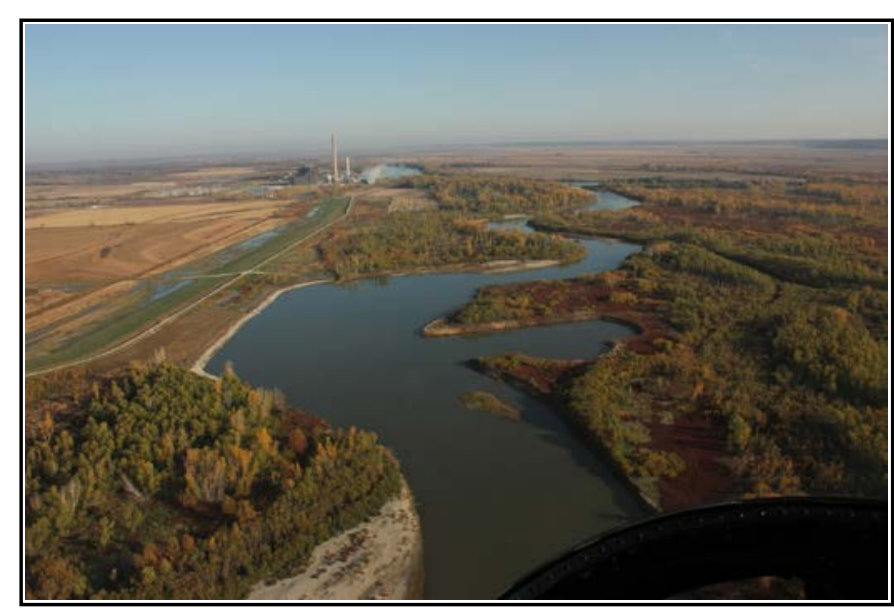

Figure 4. Repaired Upper Hamburg Bend Chute, Missouri River.

Dec atur B ridge Repair. During the 2011 flood, the Highway 175 bridge crossing the Missouri River at Decatur, NE (RM 691), experienced significant erosion along the east end bridge abutment. As part of the effort to re-open the bridge, the abutment required significant fill and armoring for protection. During the flood, a channel formed along the nose of the abutment. This channel also caused damage to the State of Iowa Upper Decatur Bend Wildlife Management Area. As the State of Iowa developed plans to repair the bridge abutment, it became clear that additional protection was needed to prevent future damage. To build up and armor the bridge, a large amount of fill material was required. The river had formed an active channel at the toe of the abutment so very little material was available close by.

To address the need for large amounts of fill material, the Iowa Department of Transportation worked with USACE and the Iowa Department of Natural Resources (IDNR) to source material that

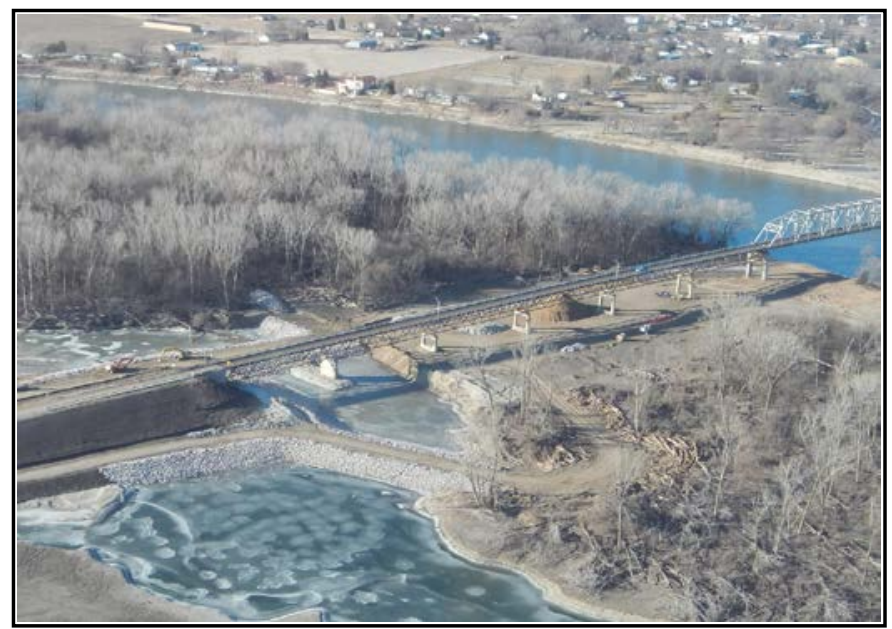

Figure 5. Bridge abutment repair at Highway 175 bridge, Decatur, NE. also benefitted habitat creation. A number of shallow wetland areas were filled during the flood, and sandbar deposits in the Missouri River needed to be removed. Through a combination of excavation to deepen the wetlands and dredging to remove the sandbars, sufficient fill was sourced to build control structures and support bank stabilization on and around the bridge abutment. Figure 5 shows the completed project in the winter of 2011/2012. The entire project was completed in a matter of months to allow the highway to reopen. 
Garrison Dam Spillway Repair. During the 2011 flood, Garrison Dam in central North Dakota used the spillway to discharge the majority of the 160,000 cubic feet per second (cfs) peak flow at the height of the flood. During the flood, sediment deposited in the spillway approach channel, which added to a large existing sediment deposit and further limited the maximum discharge of the spillway structure. (Note that the Garrison Project spillway design discharge is considerably higher than the 2011 discharge.)

While the spillway was in use, the discharge passed through a pond at the foot of the spillway, and then through an earthen pilot channel that directed flow back to the Missouri River. Due to the magnitude and duration of the flood, the earthen channel experienced major erosion, resulting in a channel 300-ft wide and 10- to 15-ft deep. The flow also eroded the earthen embankment that served as the downstream shore of the spillway pond. The pond is part of a recreation area and serves as a water intake for the Garrison fish hatchery.

As part of post-flood reconstruction, several goals were identified for the project:

- Remove deposited sediment in the spillway channel to regain maximum discharge capacity.

- Rebuild the spillway pond.

- Limit the impact of storage of a large volume of dredged material.

Figure 6 shows the spillway channel at Garrison Dam before and after the 2011 flood.

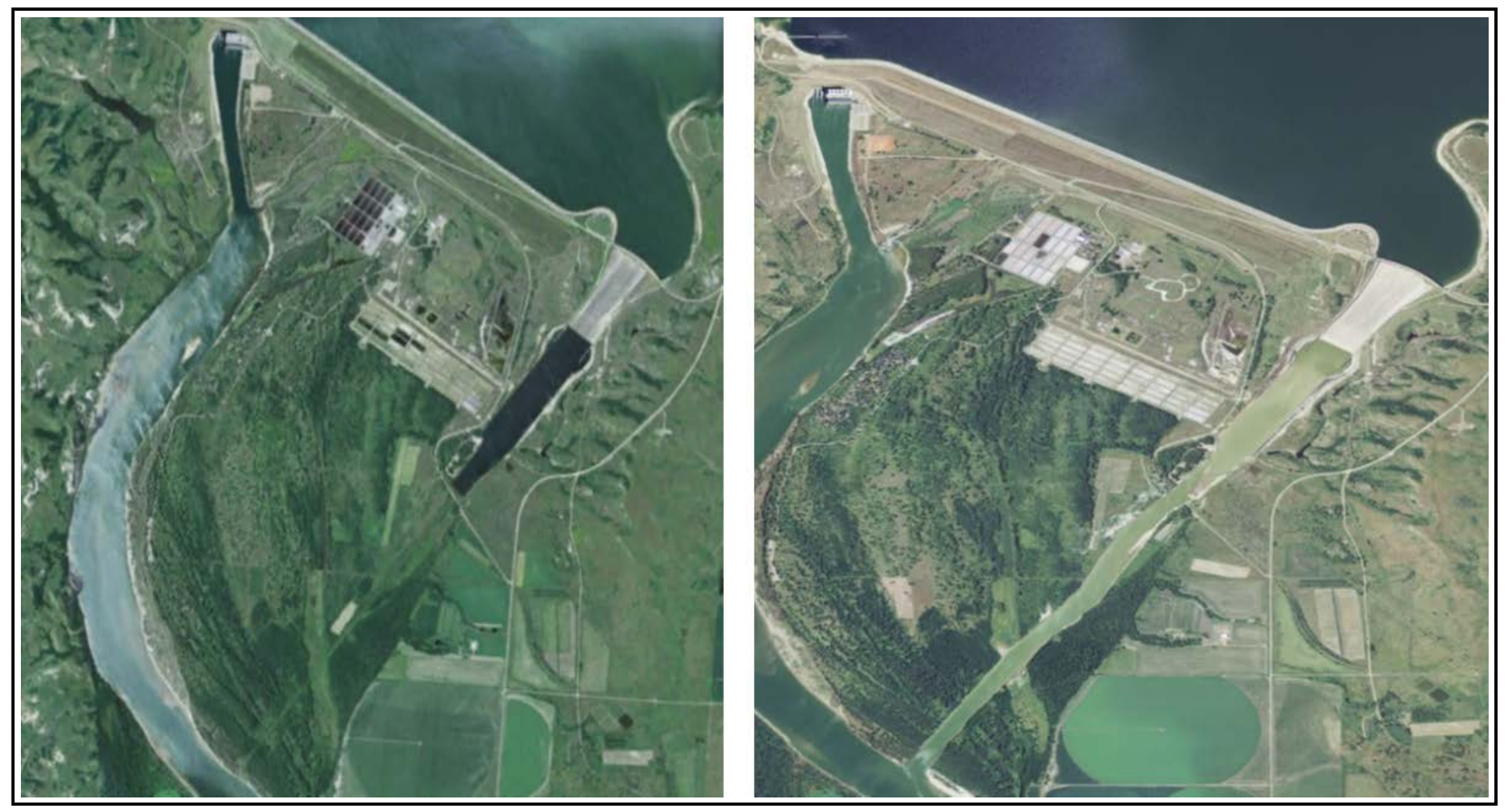

Figure 6. Garrison Dam spillway channel before (left) and after (right) the 2011 flood. 


\section{J une 2013}

Surveys of the spillway channel indicated that approximately 900,000 cubic yards (cu yd) of material would need to be removed from the channel to regain full capacity. Approximately 100,000 cu yd of that material was attributed to 2011 flood deposits. Construction of settling ponds for the material would require hundreds of acres in an area with rolling hills and steep gullies. This solution was determined to be impractical. Two other proposed discharge locations were identified with sufficient volume: (1) disposal of the dredge material upstream of the dam on the lake bottom, and (2) filling the downstream spillway channel.

A pilot channel at the bottom of the lake used during the construction of the dam provides an easy path for escape of cold water through the powerhouse at low lake levels. To reduce this impact, it was proposed to discharge the dredge material into the submerged channel to block this flow. Water quality concern expressed by permitting agencies forced consideration of other methodologies. The washed out spillway channel was the next logical site for deposition. The dredged material would serve to help rebuild the pond embankment, and could then fill the channel below. Plans were made to vary the dredge discharge location in the channel to create shallow water habitat and wetlands. This site became the preferred alternative. However, as of December 2012, funding limitations have prevented execution of the project.

\section{Lower Decatur Bend Repair.}

Lower Decatur Bend is located on the navigation channel of the Missouri River at RM 687. This site included a revetment lowering project to create shallow water habitat constructed in 2008. During the 2011 flood, sustained high flows scoured a floodplain flow path, damaged significant sections of revetment, and scoured a deep flow path behind the revetment. The widening of the river in the area also caused shoaling in the navigation channel crossover adjacent to the revetment overtopping area. Post flood surveys indicated that the authorized 9-ft-deep navigation channel was not fully supported in the crossover due to the shoaling. The primary goal of the post flood repair was to restore the navigation channel. Figure 7 shows the bend with the area eroded behind the revetment. Figure 8 shows the river depths at the flow used to assess the navigation channel depth.

Dredging was considered to be a fast solution to regain the channel capacity; in turn, the dredge material could be used to reestablish the bank behind the revetment. However, the shallow area scoured behind the revetment was useful habitat for the endangered Pallid Sturgeon.

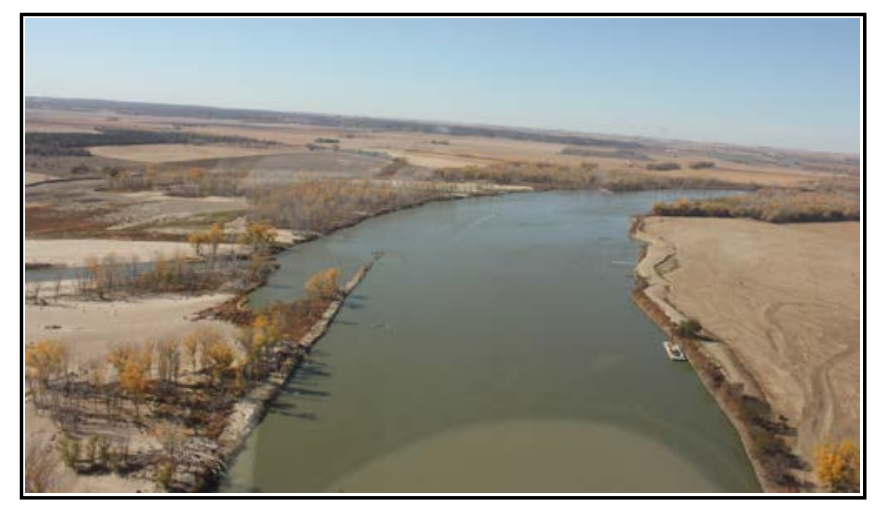

Figure 7. Lower Dec atur Bend, Missouri River, revetment erosion.

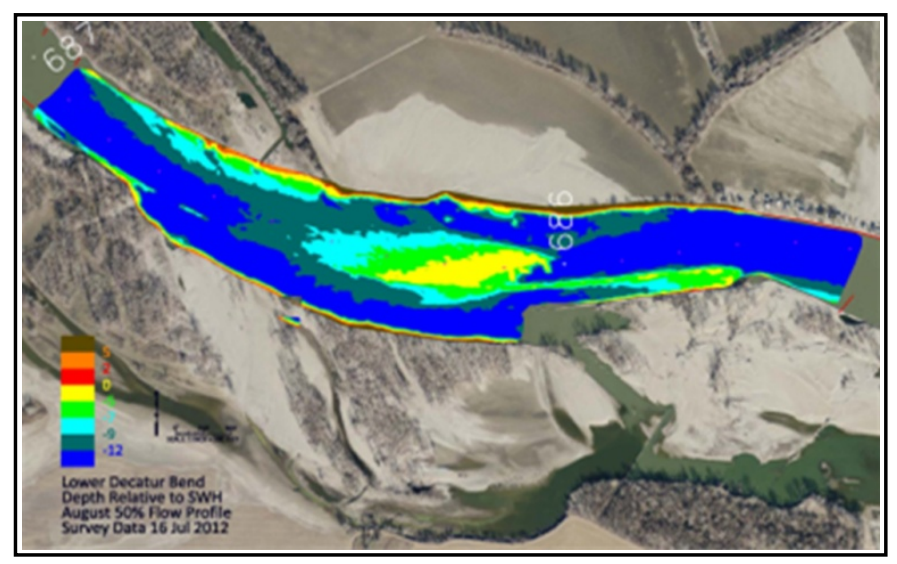

Figure 8. Channel depth in Lower Decatur Bend, Missouri River. 
A modified design was developed to use rock structures to slightly narrow the river in the shoaling area and to cause natural erosion of the sandbar. In conjunction with these structures, the revetment restoration was modified to include connectivity slots and large notches to maintain the habitat created during the flood. Figure 9 shows the Lower Decatur Bend repair plan.

\section{EMERGENCY AUTHORIZATIONS TO RETURN SEDIMENT TO THE} MISSOURI RIVER. During the 2011

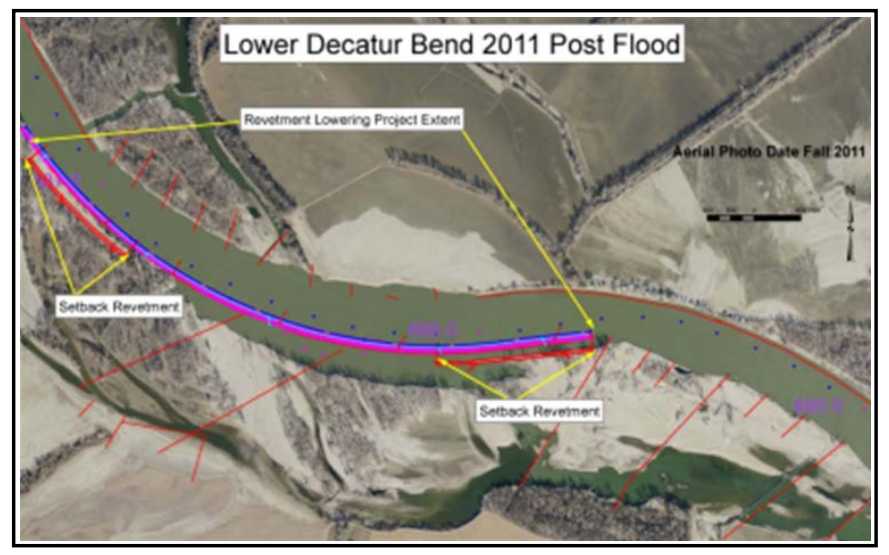

Figure 9. Lower Decatur Bend, Missour River, repair plan.

flood, vast amounts of sediment were scoured from the bed and banks of the Missouri River. The majority of this sediment was transported downstream by the river. However, a significant amount of sand and finer material was deposited in the floodplain between levees in the navigation reach, and in other flooded areas. In some locations, sand dunes in excess of $6 \mathrm{ft}$ deep remained after flood waters receded. Within a matter of days, calls were received by US Army Engineer District, Omaha (NWO), requesting permits to push these sand dunes back into the river, to dredge out marinas, and to remove sediment from parking lots and city parks.

The NWO Hydrologic Engineering Branch teamed with the Regulatory Branch and the Nebraska State Regulatory Office to develop a plan to address private and public requests for moving sediment back into the Missouri River. The primary concern from an engineering standpoint was to not overload the river with sediment. While much of the sediment was deposited at flows above 160,000 cfs, flows in late fall 2011 after the flood were in the range of 40,000 to 60,000 cfs. To address this concern, a bed material load estimate was made from existing data. Ten percent of the measured bedload of the fall flows was considered to be the upper limit for the daily rate of sediment to be returned to the river.

The permitting was established in two phases. Phase 1 was development of an emergency permit that could be processed quickly, with verbal approval to start work by phone. This permit tool was limited to the navigation channel, and only until flows dropped for the winter. The permit upper limit was set at 10,000 cu yd, but could be issued multiple times to an applicant for additional material. Phase 2 established a regional general permit through 2013 for work up to 100,000 cu yd. An organizational structure was developed to ensure that all permit requests were processed by a single person. A spreadsheet was created to schedule when and where permit applicants were adding sediment to the river. Regulatory and engineering personnel reviewed the spreadsheet for scheduling to ensure that the cumulative impact of sediment inputs did not exceed the upper limit of $10 \%$ of the measured bed material load. 


\section{LESSONS LEARNED AND PROBLEMS ENCOUNTERED.}

Project-Specific RSM Integration. The 2011 flood on the Missouri River moved sediment regionally between reservoirs and throughout the lower Missouri River. After floodwaters receded, an extremely high priority was placed on returning the system to an acceptable flood protection operation level in the shortest time possible. To that end, old designs and plans were revived, and the effort began to replicate the original design. While this was the lowest risk approach to flood restoration, it did not fully take advantage of changes in operational goals, public priorities, or possible cost savings.

At each project summarized in this CHETN, a change from the standard process was considered that included RSM benefits. Some projects resulted in successful integration, while others had obstacles that could not be surmounted in the short term. However, in all cases, the tenants of RSM were considered and an attempt was made to maximize the possible benefits of incorporating RSM. For each project, there were distinct successes and failures. A short summary for each project, and for emergency authorizations to return sediment to the Missouri River, follows:

- Hamburg Bend Chute Shallow Water Habitat. The use of local sediment for levee repair construction provided the opportunity to create a backwater habitat. The design team realized the need for additional levee repair material and went to the Missouri River Recovery Program for guidance on what would work best. One positive attribute of this effort was that RSM concepts did not need to be "forced into" the project; working through the RSM process was a natural extension of the project that inherently offered significant cost savings. In some of these projects, RSM principles offer obvious, common sense solutions; incorporating RSM is easily justified.

- Decatur Bridge Repair. This project was successful due to the highly qualified staff involved on both the State and Federal sides. Multiple meetings and site visits ensured that all parties were working with the same vision. As is often the case, working with professional staff having previous experience increases the possibility of adding other organizations that could support and/or benefit from the existing program plan.

- Garrison Dam Spillway Repair. Water quality issues directly affected the direction of this project. Costs would have been reduced considerably, along with possible increased cold water fishery habitat benefits, if the in-lake disposal option had been selected. Ultimately, water quality concerns required the change to downstream disposal. The downstream disposal included RSM in the design approach, but was not funded.

- Lower Decatur Bend Repair. This project was the perfect example of the need to determine whether a return to the previous design is warranted. The goal of the project is still to return the navigation channel to full functionality. However, that goal is being accomplished without dredging while maintaining habitat created during the flood.

- Emergency Authorizations to Return Sediment to the Missouri River. Ultimately, a great program is only great if adequately publicized. A key obstacle while obtaining the emergency permits was keeping the public fully informed. Public outreach is not normally a large function of NWO Regulatory Branch but, in this case, the lack of information dissemination and some confusion by state agencies limited the effectiveness of the program. 
Post-Flood RSM Integration. On a larger scale, key lessons learned while incorporating RSM principles during the 2011 Missouri River flood recovery include:

- The most important factor in integrating RSM principles into a project is to have the appropriate team members available. Often it becomes a prioritization of available staff as much as it is a sediment decision when incorporating RSM principles. Such decisions regarding staff availability and their functional prioritization should be made at the highest level when working with RSM issues.

- Many USACE Districts do not routinely seek independent guidance regarding incorporation of RSM concepts when developing project plans. In cases where incorporation of RSM concepts into projects could have distinct benefits, it may be important that appropriate professional staff bring such knowledge to the attention of decision makers either by volunteering to become a member of the Product Development Team (PDT) and/or by providing RSM information to other existing PDT team members.

- Marketing RSM principles to permitting agencies may or may not be entirely successful. Regarding the Garrison Dam Spillway project, water quality concerns from the state resource agencies guided the design process. RSM program reports and Technical Notes are invaluable for presenting such agencies with similar successful projects.

- Dredging is not always the answer to an RSM initiative. Even small creeks move more sediment than an average dredge, and they do so 24 hours a day. Enabling the river to do the work of moving sediment is often far more cost effective, and may cause fewer local adverse impacts (of less severity) than dredging.

- Communication is the key for disseminating knowledge about a project that has incorporated RSM concepts into its design. If a program has been developed to assist the public and if it contains RSM initiatives, the local constituents should be fully informed about these RSM components, else the benefits may not be fully understood.

CONCLUSIONS. Flood recovery activities on the Missouri River occurred at a rapid pace for about 12 months during the latter part of calendar year 2011 and into 2012. From October 2011 (when the water receded) until the start of the 2012 navigation season (when the navigation channel became operational), work proceeded at a very rapid pace. Roads and bridges were repaired within weeks to a few months, and levees were repaired by early 2012. There was little time for brainstorming and creative thinking. The primary goal was always to re-establish full service of all authorized project purposes as quickly as possible. In the process of meeting that goal, all available opportunities were taken to integrate RSM principles into many of the flood recovery projects.

RSM was not integrated into every flood recovery project. Some projects were not the type for which RSM concepts could be capitalized, and some projects had very restrictive design criteria. Other projects, however, were good candidates for developing RSM designs that benefitted other regional projects as well as the intended local project.

ADDITIONAL INFORMATION. This CHETN was prepared as part of the US Army Corps of Engineers Regional Sediment Management (RSM) program. The US Army Engineer District, Omaha, Point of Contact (POC) for this study, and author of this CHETN, was Paul M. Boyd. Additional information regarding RSM can be found at the RSM website: http://rsm.usace.army.mil 


\section{J une 2013}

Questions regarding this CHETN may be addressed to:

Paul M. Boyd

(USACE Omaha District RSM POC)

Linda S. Lillycrop

Paul.M.Boyd@usace.army.mil

(USACE RSM Program Manager)

Linda.S.Lillycrop@usace.army.mil

This ERDC/CHL CHETN-XIV-29 should be cited as follows:

Boyd, P. M. 2012. Regional Sediment Management (RSM) principles in flood recovery. Coastal and Hydraulics Engineering Technical Note ERDC/CHL CHETN-XIV-29. Vicksburg, MS: US Army Engineer Research and Development Center, Coastal and Hydraulics Laboratory (ERDC-CHL), http://chl.erdc.usace.army.mil/library/publications/chetn/pdf/chetn-xiv-29.pdf

\section{REFERENCES.}

Grigg, N., C. McCarthy, B. Lawrence, and D. Ockerman. 2012. Review of the Regulation of the Missouri River Mainstem Reservoir System during the Flood of 2011. Omaha, NE: Independent Review Panel for the US Army Engineer District, Omaha.

USACE. 2012. Missouri River Mainstem Reservoir System: Summary of Actual 2011 Regulation. Portland, OR: US Army Engineer Division, Northwestern.

\section{ACRONYMS AND ABBREVIATIONS.}

\begin{tabular}{|l|l|}
\hline Term & Definition \\
\hline CHETN & Coastal and Hydraulics Engineering Technical Note \\
\hline CHL & Coastal and Hydraulics Laboratory \\
\hline ERDC & Engineer Research and Development Center \\
\hline IDNR & lowa Department of Natural Resources \\
\hline MAF & million acre-ft \\
\hline MRRP & Missouri River Recovery Program \\
\hline NWO & US Army Engineer District, Omaha \\
\hline OSRT & Omaha System Restoration Team \\
\hline PDT & Product Development Team \\
\hline POC & Point of Contact \\
\hline RM & River Miles \\
\hline RSM & Regional Sediment Management \\
\hline US & United States \\
\hline USACE & US Army Corps of Engineers \\
\hline
\end{tabular}

NOTE: The contents of this technical note are not to be used for advertising, publication, or promotional purposes. Citation of trade names does not constitute an official endorsement or approval of the use of such products. 